\title{
SCHOOL BULLYING IN THE MIDDLE SCHOOL: COMPARISON OF VIOLENCE PREVENTION PROGRAMS
}

\author{
Zeynep TURHAN \\ Assistant Prof. Dr., Bartin University, Department of Social work, Bartin / TURKEY, \\ zturhan@bartin.edu.tr
}

\begin{abstract}
Many studies show violent behavior patterns increase during adolescence because peer pressure might encourage adolescents to bully or become victims, depending on environmental factors such as the relationship with their family members and friends. During adolescence, any action affects not only brain development but also emotional development. Early prevention programs might prevent or reduce aggressive and violent behavior in this period. This article critically compares two different school bullying prevention programs including the Olweus Bully Prevention Program (OBPP) and the Second Step Violence Prevention Program (SSPP). This comparison aims to prevent school bullying and to understand the implications in regard to short or long terms solutions and using cost-effective strategies to define the roles for school professionals. The focus of this article is on comparing different universal anti-bullying programs, such as the OBPP and the SSPP among the middle-school-age children. Making a comparison, each school has a different amount of priorities in terms of using the prevention program. The article contributes to debates about school violence prevention programs by highlighting the importance of the schools' responsibility for selecting the best program for their students.
\end{abstract}

Keywords: bullies, adolescence, school bullying, prevention programs

\section{INTRODUCTION}

The studies around bullying prevention have been initiated around 1970s in Scandinavia (Olweus, 1973, 1978). While different types of bullying exist, bullying is identified as power imbalance between perpetrators and his or her victims. Likewise, bullying is mostly associated with aggressive behavior (Gladden et al., 2014; Olweus, 1993). Olweus, (1993) defines bullying as, "the exposure repeatedly and over time, to negative actions on the part of one or more other persons, and he or she has hardly defending himself or herself" ( $p$. 32). This definition emphasizes that bullies continually subject their victims to harm, and shows that school bullying is one of the most critical social problems. Childhood bullying may leave a person with psychological problems which may impact them over the course of their entire lives (Shariff, 2008).

In schools, many youths commit suicide or try to damage themselves or their friends. Physical and psychological bullying cause important consequences such as lower self-esteem (Cook et al., 2010; Shariff, 2008). Without any prevention or insufficient support system, bullying might be detrimental. Increasing 
violence and bullying at school compels professionals to develop more effective prevention programs. School principals, teachers and parents hold significant positions in achieving successful bullying prevention process. This article aims to find ways to prevent the increase of violence among middle school youths by critically comparing two different bullying prevention programs, OBPP and SSPP.

Several researchers found the consequences of bullying among students who have ben bullied. For instance, the problems around mental health, behavioral patterns and psychology are often identified as significant consequences of bullying (Cook et al., 2010; National Academies of Sciences, 2016). These consequences might result in internalizing problems such as poor self-esteem and depression (Olweus, Limber, \& Breivik, 2019). On the other hand, children and youth bullies often apply externalizing behavior (Olweus, Limber, \& Breivik, 2019) For instance, bullies often break the rules, use violent behavior and apply abusive acts.

Some scholars examined whether characteristics of young people contribute to increased bullying (Limber et al., 2018; Van Schoiack-Edstrom et al., 2002). For example, aggressive youths' self-appraisal has been identified as a significant factor for their inappropriate behavior (Van Schoiack-Edstrom, Frey, \& Beland, 2002). Likewise, youths who apply bullying behavior might see themselves as relatively hopeless at managing their aggression and anger. They are more likely to use physical aggression while solving their problems (Van Schoiack-Edstrom et al., 2002). During adolescence, early prevention programs customarily prevent and reduce potential aggressive as well as violent behavior (Limber et al., 2018; Dan Olweus et al., 2019; Van Schoiack-Edstrom et al., 2002).

Bullies and victims have different types of characteristics, depending on their gender, age, environmental factors, and their relationships with their friends, teachers and family members. All these different factors contribute to whether one is susceptible to becoming a victim or a perpetrator. Olweus (1993) defines victims' characteristics as "cautious, sensitive and quiet" (p. 32). Olweus (1993) further states that:

When they are attacked by other students, they commonly react by crying (at least in the lower grades) and withdrawal. Also, victims suffer from low self-esteem, and they have a negative view of themselves as failures and feel stupid, ashamed and unattractive. (p. 32)

Survivors are more likely to behave in a withdrawn manner and they may suffer from lowered confidence. These attitudes may prevent them from talking about their problem (Olweus, 1993). On the other hand, bullies hold the opposite behaviors. Bullies are often identified with common characteristics. These are the tendency of being violent, more abusive actions than their friends. These characteristics are associated with dominating others and lack of controlling themselves (Olweus, 1993). In addition, Reed (2007) states that bullies seek out victims who are "weaker" among the middle school bullies for retaining their popularity.

Many types of bullying can be easily identified such as the more overtly violent bullies. However, relational bullying such as isolation is more difficult to see as it is more secretive. Relational aggression is one type of bullying behavior, and relational aggression is usually observed among girls. Young, Nelson, Hottle, Warburton and Young, (2011) defines relational aggression as: "...harm within relationships caused by covert bullying or manipulative behavior" (p. 25). The examples for relational aggression may include isolating a youth from his or her group of friends and making social media as a threat.

These characteristics described above help educators to understand youths' attitudes such as violent behavior or withdrawal. Depending on these specific characteristics, educators make a decision about which exercise or program is the most effective in preventing bullying for young people at schools. According to Reed (2007) the middle school bullying behaviors are interconnected with students' confusion around their physical and psychological changes during puberty. In adolescence, obtaining social skills might depend on the experiences during pre-school years. In this sense, violence preventions such as improving social skills before adolescence years is vital for potential bullying attitudes during puberty (Nicolet, 2004). Youths might use violent or aggressive behavior when they face some problems with their peers. To prevent these potential violent behaviors, using prevention programs improve their social skills and this can ensure their well-being.

The target of youth violence prevention programs might shape the successful outcomes in a program. For instance, Matjasko et al., (2018) reviews the studies of violence prevention evaluations that conducted metaanalysis and systematic reviews. In this review, they focused on prevention approach, program type, and study design. The most of the program effects were moderate. However, preventions concentrating on family illustrated customarily lager effects than targeting school, community and treatment specific or general types (Matjasko et al., 2018). Collaboration between schools and families allows youths opportunities to reduce the negative effects of bullying, because students may receive more support and knowledge from parents and 
teachers. In schools, some ideal programs have a collaborative approach (Nicolet, 2004). Importantly, the roles of families in involving these prevention efforts can be essential because their efforts might help students follow prevention activities and guidance across schools (Leff, Power, Manz, Costigan, and Nabors, 2001). Therefore, family members often hold critical roles on the students' improvements of healthy behavioral patterns.

The studies of the evaluation of school bullying preventions illustrate the importance of implementing these programs for the reduction of bullying behavior and improving the social-emotional skills. Therefore, bullying preventions can be promising to develop healthier and positive interactions among young people at schools. For instance, several scholars found that school bullying prevention programs are helpful to reduce and stop different types of bullying behavior (Espelage et al., 2015; Gaffney et al., 2019; Jiménez-Barbero et al., 2016). For instance, Bauer, Lozano, and Rivara, (2007) examined the effectiveness of OBPP and conducted surveys with 10 public schools. While the overall of effect of prevention was positive, gender, ethnicity/race, and grade were identified as factors for some mixed positive effects. However, these factors did not impact the overall results. Likewise, Gaffney et al., (2019) found the positive results of the school bullying preventions by conducting systematic review and meta-analysis. They stated that "anti-bullying programs reduce school bullying perpetration by approximately $19-20 \%$ ad school-bullying victimization by approximately $15-16 \% "$ (p. 111).

\section{METHOD}

A critical literature review was used for this article. To compare two common preventions of OBPP and the SSPP at schools, this comparison will help us find answers to the following questions. These questions are: What are the key differences of two different bullying prevention programs in terms of short term and longterm solutions and effective time, especially in middle school? What can we recommend so that middle school children can go to school without experiencing bullying behavior? To answer these questions, this study first defines the characteristics of these programs and compares them on the Table 1.

A critical literature review was used for this article. To compare two common preventions of OBPP and the SSPP at schools, this comparison will help us find answers to the following questions. These questions are: What are the key differences of two different bullying prevention programs in terms of short term and longterm solutions and effective time, especially in middle school? What can we recommend so that middle school children can go to school without experiencing bullying behavior? To answer these questions, this study first defines the characteristics of these programs and compares them on the Table-1. The Table-1 below shows the characteristics of OBPP and SSPP.

Table-1. Comparing OBPP and the SSPP

\begin{tabular}{|l|l|l|}
\hline Characteristics & \multicolumn{1}{|c|}{ OBPP } & \multicolumn{1}{|c|}{ SSPP } \\
\hline Level of School & Elementary, middle and high school & Pre/K-Grade 8 (elementary and middle school) \\
\hline Program Goals & $\begin{array}{l}\text { Improving peer relations, promoting } \\
\text { a safe and positive school } \\
\text { environment. }\end{array}$ & $\begin{array}{l}\text { Decreasing violence, aggression, bullying, } \\
\text { substance abuse, and increasing school } \\
\text { success }\end{array}$ \\
\hline $\begin{array}{l}\text { Teaching } \\
\text { Strategies at }\end{array}$ & $\begin{array}{l}\text { Establishing a Bullying Prevention } \\
\text { Coordinating Committee; conducting } \\
\text { committee and staff trainings; } \\
\text { administering the Olweus Bullying } \\
\text { Questionnaire school wide } \\
\text { (Hazelden, 2007). }\end{array}$ & $\begin{array}{l}\text { Using rich multi-media content to accompany } \\
\text { each lesson; engaging lesson videos; carefully } \\
\text { constructing approach to partner and group } \\
\text { work; providing individual reflection by } \\
\text { reviewing the core skills. }\end{array}$ \\
\hline $\begin{array}{l}\text { Program } \\
\text { Themes }\end{array}$ & $\begin{array}{l}\text { To reduce students' bullying } \\
\text { behavior and improve safe school } \\
\text { environment; to improve students' } \\
\text { positive and healthier relationship } \\
\text { with their friends at school (Olweus, } \\
\text { 1993). }\end{array}$ & $\begin{array}{l}\text { To gain empathy and communication, emotion } \\
\text { management; to cope with stress by applying } \\
\text { appropriate problem-solving skills and decision } \\
\text { making. }\end{array}$ \\
\hline $\begin{array}{l}\text { Program } \\
\text { Components }\end{array}$ & $\begin{array}{l}\text { School-level components Individual- } \\
\text { level comp. }\end{array}$ & $\begin{array}{l}\text { Teacher's Guide, lessons, lesson companion } \\
\text { DVD, teaching the Program DVD, resources }\end{array}$ \\
& $\begin{array}{l}\text { Classroom-level comp. } \\
\text { Community-level comp (Bauer, } \\
\text { Lozano, and Rivara, 2007). }\end{array}$ & $\begin{array}{l}\text { CDOM, posters, supplemental materials, } \\
\text { access to Second Step, middle school client } \\
\text { extranet, lifetime program support }\end{array}$ \\
\hline
\end{tabular}


As can be seen the Table 1, OBPP is broader than SSPP in regard to program components. OBPP influences not only students' social developmental but also school success. The association between bullying prevention and improving positive attitudes and achievements is significant. Olweus and Limber (2010) found that the OBPP mostly improve safe and positive school environment and students' academic development. While the OBPP focuses on improving peer relations, promoting a safe, positive school environment, the SSPP aims to decrease violence, aggression, bullying and substance abuse. Both eventual goals are increase school success and safe environment. Taub (2002) emphasizes improving social competence and reducing anti-social behaviors under the SSPP classroom-based program. Given the logical comparison of prevention programs, the section moves on to discussing the implementation of these programs in middle schools.

\section{RESULTS}

Every school strives to keep students safe, and they want to select one program to prevent or reduce school bullying. Many research findings highlight OBPP and SSPP as effective programs for preventing multiple kinds of violence within the school. Under SSPP among middle-school-age youth, Van Schoiack-Edstrom et al. (2002) reported that students who access the Year 1 and Year 2 programs both demonstrated increases in prosocial skills. Specifically, Year 1 students reported less tolerance for social exclusion, while Year 2 students reported the greatest gains in overall social competencies (Van Schoiack-Edstrom et al. 2002). This study shows that the SSPP program is helpful to improve youths' social skills (Nicolet, 2004).

Many schools struggle with delivering the right prevention program, which is a significant decision-making process. For example, school staff may face obstacles to implementing prevention program and evaluating the effectiveness of this program (Rosenberg et al., 1997). Therefore, schools might not be able to make decision about the appropriate prevention curriculum (Nicolet, 2004). Time is one of the significant factors in selecting a cost-effective prevention program, because many educators tend not to waste their time in weekly class meetings and preparing materials at activities. Some teachers have to spend much time preparing students for tests, so they are often reluctant to learning as well as and implementing bullying programs. This pressure about timing may not allow them to use prevention programs properly. Even though the school staff are often resistance setting aside time for these programs' activities and meetings, evidence illustrates the importance of delivering prevention programs at schools (Olweus and Limber, 2010). As a result, certain barriers such as lack of support of the school's leader and educators affect to change the climate of school positively (Limber, 2011).

\section{CONCLUSION}

Receiving parents' and school's attention for increasing the using of prevention programs is key to reduce violence in schools. Focusing on reducing and preventing bullying in the school ensures that school staff selects the most effective prevention programs. However, selecting the best program does not happen for every school. In middle school, depending on the socio-economic status and youth characteristics, bullying behavior might be different. So, schools should be aware of these differences while selecting prevention programs and keeping students safe. Choosing the appropriate prevention programs for schools, using these programs without wasting time, and putting the priority of selecting appropriate plan allow them to obtain positive outcomes. In regard to comparing the programs, the SSPP is cheaper than the OBPP, so some schools might prefer the cheaper one as a cost-effective strategy. Overall, it would be argued that the schools should recognize the importance of violence prevention programs for safer, healthier and respectful school environment for children's well-being.

\section{REFERENCE LIST}

Bauer, N. S., Lozano, P., \& Rivara, F. P. (2007). The effectiveness of the Olweus bullying prevention program in public middle schools: A controlled trial. Journal of Adolescent Health, 40(3), $266-274$. https://doi.org/10.1016/j.jadohealth.2006.10.005

Cook, C. R., Williams, K. R., Guerra, N. G., Kim, T. E., \& Sadek, S. (2010). Predictors of bullying and victimization in child- hood and adolescence: A meta-analytic investigation. School Psychology Quarterly, 25, 65-83.

Cook, R. C., Williams, K. R., Guerra, N. G., Kim, T. E., \& Sadek, S. (2010). Predictors of bullying and victimization in childhood and adolescence: a meta-analytic investigation. School Psychology 
Quarterly, 25, 65-83.

Espelage, D. L., Rose, C. A., \& Polanin, J. R. (2015). Social-emotional learning program to reduce bullying, fighting, and victimization among middle school students with disabilities. Remedial and Special Education, 36(5), 299-311. https://doi.org/10.1177/0741932514564564

Evans, C. B. R., Fraser, M. W., \& Cotter, K. L. (2014). The effectiveness of school-based bullying prevention programs: A systematic review. Aggression and Violent Behavior, 19(5), 532-544. https://doi.org/10.1016/j.avb.2014.07.004

Gaffney, H., Ttofi, M. M., \& Farrington, D. P. (2019). Evaluating the effectiveness of school-bullying prevention programs: An updated meta-analytical review. Aggression and Violent Behavior, 45(July 2018), 111-133. https://doi.org/10.1016/j.avb.2018.07.001

Gladden, R. M., Vivolo-Kantor, A. M., Hamburger, M. E., \& Lumpkin, C. D. (2014). Bullying surveillance among youths: Uniform definitions for public health and recommended data elements, version 1.0.

Jiménez-Barbero, J. A., Ruiz-Hernández, J. A., Llor-Zaragoza, L., Pérez-García, M., \& Llor-Esteban, B. (2016). Effectiveness of anti-bullying school programs: A meta-analysis. Children and Youth Services Review, 61, 165-175. https://doi.org/10.1016/j.childyouth.2015.12.015

Leff, S. S., Power, T. J., Manz, P. H., Costigan, T. E., \& Nabors, L. A. (2001). School-based aggression prevention programs for young children: Current status and implications for violence prevention. School Psychology Review, 30(3), 344-362.

Limber, S. P., Olweus, D., Wang, W., Masiello, M., \& Breivik, K. (2018). Evaluation of the Olweus bullying prevention program: A large scale study of U.S. students in grades 3-11. Journal of School Psychology, 69(April), 56-72. https://doi.org/10.1016/j.jsp.2018.04.004

Matjasko, J. L., Vivolo-kantor, A. M., Massetti, G. M., Holland, K. M., Holt, M. K., \& Cruz, J. Dela. (2018). A systematic meta-review of evaluations of youth violence prevention programs: Common and divergent findings from 25 years of meta-analyses and systematic reviews. Aggression and Violent Behavior, 17(6), 540-552. https://doi.org/10.1016/j.avb.2012.06.006.A

National Academies of Sciences, E. and M. (2016). Preventing bullying through science, policy, and practice.

Nicolet, I. A. (2004). The second step violence prevention program: effectiveness of a brief social skills curriculum with elementary-age children.

Olweus, D. (1973). Hackkycklingar och översittare. Forskning om skolmobbing. Almqvist \& Wicksell.

Olweus, D. (1978). Aggression in the schools: Bullies and whipping boys. Hemisphere Press.

Olweus, D. (1993). Bullying at school: what we know and what we can do. Blackwell Publishers Ltd.

Olweus, D., \& Limber, S. P. (2010). Bullying in school: evaluation and dissemination of the Olweus bullying prevention program. American Journal of Orthopsychiatry, 80(1), 124-134.

Olweus, Dan, Limber, S. P., \& Breivik, K. (2019). Addressing specific forms of bullying: A large-scale evaluation of the Olweus bullying prevention program. International Journal of Bullying Prevention, 1(1), 70-84. https://doi.org/10.1007/s42380-019-00009-7

Reed, A. L. (2007). "I won't think about it the same way again": critical literacy as an anti-bullying tool in the middle school setting". Information and Learning Company: ProQuest.

Rosenberg, M. L., Powell, K. E., \& Hammond, R. (1997). Applying science to violence prevention. Journal American Medical Association, 28(277(20)), 1641-1642.

Shariff, S. (2008). Cyber-bullying: Issues and solutions for the school, the classroom and the home. Routledge.

Taub, J. (2002). Evaluation of the Second Step Violence Prevention Program at a rural elementary school. School Psychology Review, 31(2), 186-200.

Van Schoiack-Edstrom, L., Frey, K. S., \& Beland, K. (2002). Changing adolescents' attitudes about relational and physical aggression: An early evaluation of school-based intervention. School Psychology Review, 31(2), 201-216.

Young, E. L., Nelson, D. A., Hottle, A. B., Warburton, B., \& Young, B. K. (2011). Relational aggression among students. The Education Digest, 76(7), 24-29. 